\title{
Catalytic Oxidation of Corn Straw by NiO under Hydrothermal Conditions to Produce Lactic Acid
}

\author{
Mingxin Sun, Weiyi Li, Fengling Zeng, Nianyi Zhang, Fengwen Wang* \\ School of Resources and Environment, Anhui Agricultural University, \\ 130 West Changjiang Road, Hefei 230036, China
}

Received: 22 June 2021

Accepted: 30 October 2021

\begin{abstract}
To make full use of cornstalks from biomass waste, a green method for producing high value-added chemical products like organic acid with nickel oxide $(\mathrm{NiO})$ as a solid oxidant was studied. The results show that the liquid product contains formic acid, lactic acid, pyruvic acid, oxalic acid and fumaric acid, etc. The yield of lactic acid was studied primarily. It was found that when the dosage of $\mathrm{NiO}$ is $3.5 \mathrm{mmol}$, the concentration of $\mathrm{NaOH}$ is $3 \mathrm{M}$, the reaction temperature is $230^{\circ} \mathrm{C}$ and the reaction time is 3 hours, the yield of lactic reached $15.3 \%$. In addition, the principles behind the conversion of cornstalks into organic acid with $\mathrm{NiO}$ was preliminary discussed. These results can offer a new method of developing a sustainable way for the efficient utilization of biomass waste.
\end{abstract}

Keywords: catalytic oxidation, cornstalks, biomass waste, organic acid

\section{Introduction}

Lactic acid is an important chemical product, which is widely used in food, medicine and industry. The main industrial methods of production of lactic acid are synthesis and fermentation, but both of them have disadvantages. Fermentation consumes grain and has a long product cycle, while the consumption of fossil fuels in synthesis not only contributes to greenhouse gas emissions [1-5], but also exacerbates the energy crisis [6-8]. In order to make up for the deficiencies of these two methods and to realize sustainable development, green production methods need to be explored.

Biomass is a renewable carbon-neutral clean energy source and can be used as an alternative to traditional

*e-mail: 1922146451@qq.com fossil energy [9-11]. China is capable of producing about 1.04 billion tons of straw biomass every year [12], and straw biomass' utilization prospects are very broad. The main component of crop straw is cellulose and lignin, and utilization can be realized through a variety of technologies [13], such as thermal degradation and enzymatic fermentation technology. Insoluble organic compounds such as cellulose become soluble in high-temperature water (HTW) because they have large ion products and weak hydrogen bonds [14-17]. The main hydrolytic products of cellulose in high-temperature water include erythrose, glucose, fructose, dihydroxyacetone and oligosaccharides [18]. When metal oxides and alkaline catalysts are added, the hydrolysates of cellulose can be transformed into high-value chemical products such as formic acid, lactic acid and acetic acid [19, 20]. Therefore, compared with traditional technology for cellulose utilization, hydrothermal technology has more advantages 
in the production of high value-added chemical products.

Studies have shown that $\mathrm{CuO}$ can convert biomass such as microalgae and cellulose into organic acids such as formic acid, acetic acid and lactic acid under hydrothermal conditions, and that $\mathrm{NiO}$ can also convert cellulose into organic acids such as formic acid, acetic acid and lactic acid [5, 21, 22]. However, the present study mainly investigates the reduction effect of cellulose by $\mathrm{NiO}$ under hydrothermal conditions. The process of cellulose conversion to organic acids is not deeply studied. And this is also true for the conversion of straw biomass waste to organic acids. Therefore, this paper discusses the conversion of biomass waste containing cellulose or glucose into organic acids such as lactic acid, a chemical product with high added value, under hydrothermal conditions, and obtain the highest yield and optimal reaction conditions of organic acids, so as to realize efficient utilization of biomass waste and provide a new green and environmental protective method for the preparation of organic acids such as lactic acid.

\section{Experimental}

\section{Experimental Materials}

The phosphoric acid ( $\geq 85 \%$ ), nickel oxide ( $>98.0 \%$ ), formic acid ( $\geq 98.0 \%)$, oxalic acid $(\geq 99.5 \%)$, fumaric acid $(\geq 99.0 \%)$ and pyruvic acid $(\geq 98.5 \%)$ used in this experiment were purchased from Sinopharm Chemical Reagents Co., Ltd. Sodium hydroxide ( $\geq 96.0 \%)$, concentrated sulfuric acid (95.0\%-98.0\%), anhydrous sodium sulfate $(\geq 99.8 \%)$, sodium chloride ( $\geq 99.5 \%)$ and methylene chloride $(\geq 99.5 \%)$ were purchased from Xilong Scientific Co., Ltd. Methanol ( $\geq 99.9 \%$ ) was purchased from CINC High Purity Solvents (Shanghai) Co., Ltd. Lactic acid (1 M) was purchased from Sigma Aldrich (Shanghai) Trading Co., Ltd. Corn straw was taken from the farmland of Lujiang experimental station of Anhui Agricultural University (Anhui, China). None of the reagents used in the experiment were purified.

\section{Experimental Procedure}

All experiments were performed in a teflon lined stainless steel batch reactor $(30 \mathrm{ml}$, Wuxi Nanfang Seiko automobile maintenance machinery factory, China) with an internal volume of $27 \mathrm{~mL}$. Reagents such as $\mathrm{NaOH}, \mathrm{NiO}$, corn straw powder passing 80 mesh sieve (mesh size: $0.18 \mathrm{~mm}$, Zhejiang Shangyu
Jinding standard sieve factory, China) and water $(10 \mathrm{~mL})$ were added to a sealed reactor. And then the reactor was put into an oven (DHG-9078A, Shanghai Jinghong Experimental Equipment Co., Ltd., China) preheated to the required temperature for reaction. After the reaction reached the set time, the reactor was taken out and cooled to room temperature, finally solid and liquid samples were collected. The liquid samples were filtered by $0.22 \mu \mathrm{m}$ membrane and were conducted high performance-liquid chromatography (HPLC) analysis, and gas chromatography-mass spectrometry (GC-MS) (Trace GC+ITQ 1100, Thermo Fisher, USA) analysis next. Besides, the solid samples were conducted X-ray diffractometer (XRD) (XD-2/3, Beijing puxie General Instrument Co., Ltd., China) analysis. A fully automatic element analyzer (Vario EL Cube, German element analysis system, Germany) was used for element analysis of corn straw.

\section{Product Analysis}

The concentration of lactic acid was determined by a high-performance liquid chromatograph (STI-501, Sage Technology (Hangzhou, China) Co., Ltd.) equipped with 2 Shodex KC811 chromatographic columns in series and UV detector. H3PO4 (0.1\%) was used as the carrier with a flow rate of $1.0 \mathrm{~mL} / \mathrm{min}$. The sample injection volume was $20 \mu \mathrm{L}$ and column temperature was $50^{\circ} \mathrm{C}$. The liquid samples were analyzed by GC-MS after esterfying with sulfuric acid-methanol solution [20]. The solid samples were analyzed by XRD after washing with water and ethanol and then dried [20]. As for the elemental analysis of cornstalks, which was conducted by fully automatic element analyzer, the sample injection volume was $5 \mathrm{mg}$, the temperature was $950^{\circ} \mathrm{C}$ and detecting time was $90 \mathrm{~s}$. The relative deviation of $\mathrm{C}, \mathrm{H}$ and $\mathrm{N}$ were $\leq 0.1 \%$. Contents of main elements are shown in Table 1.

The yield of organic acid is defined as the percentage of the carbon amount of some organic acid in the liquid mixture to the total carbon amount of the added straw:

$\operatorname{yield}(\%)=\frac{\text { carbon amount in lactic acid in liquid mixture after reaction }}{\text { total carbon amount in added straw }} \times 100 \%$

\section{Results and Discussion}

\section{Effect of $\mathrm{NaOH}$ Concentration on Cornstalks Conversion to Lactic Acid}

Fig. 1 shows the effect of $\mathrm{NaOH}$ concentration on cornstalks conversion to lactic acid. With the increase

Table 1. Content of various elements in cornstalks.

\begin{tabular}{|c|c|c|c|c|}
\hline $\mathrm{N}(\%)$ & $\mathrm{C}(\%)$ & $\mathrm{H}(\%)$ & $\mathrm{C} / \mathrm{N}$ & $\mathrm{C} / \mathrm{H}$ \\
\hline 0.862 & 43.627 & 5.989 & 50.611 & 7.285 \\
\hline
\end{tabular}




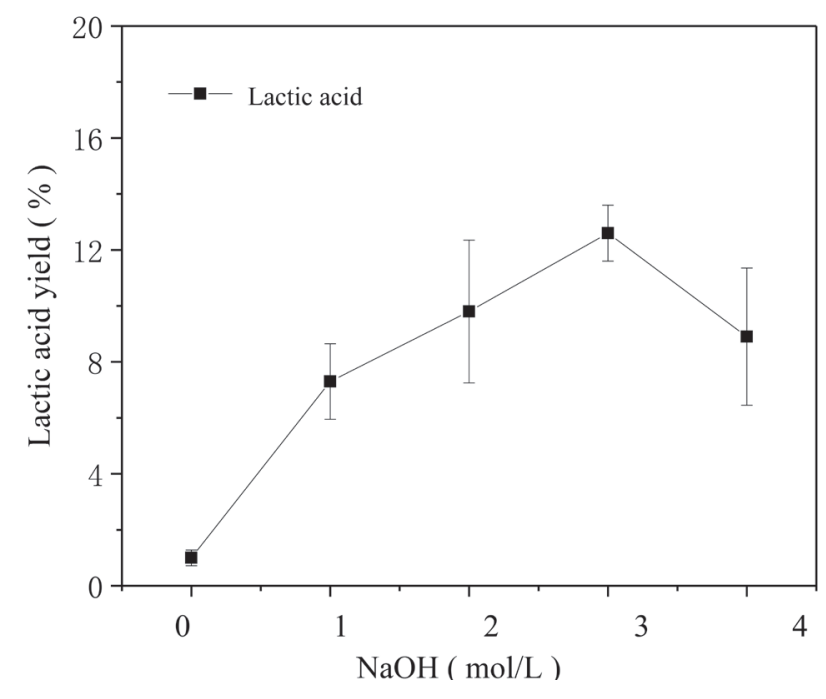

Fig. 1. Effect of $\mathrm{NaOH}$ concentration on cornstalks conversion to lactic acid ( $3 \mathrm{~h}, 1.2 \mathrm{~g}$ cornstalks, $3 \mathrm{~mol} / \mathrm{L} \mathrm{NaOH}$ ).

of $\mathrm{NaOH}$, the yield of lactic acid shows a trend of increasing at first and then decreasing. When $\mathrm{NaOH}$ is not added, the yield of lactic acid is the lowest, which is $1.0 \%$. When the concentration of $\mathrm{NaOH}$ increases from 0 to $3 \mathrm{~mol} / \mathrm{L}$, the yields of lactic acid are highest, which is $12.6 \%$. The increment is $11.6 \%$. But if the concentration of $\mathrm{NaOH}$ continues to increase to $4 \mathrm{~mol} / \mathrm{L}$, the yields of lactic acid drop to $8.9 \%$ instead. It means that the presence of alkaline (OH-) can enhance the oxidation of chlorella to lactic acid in a certain range. However, if the concentration of alkaline is too high, the conversion may be inhibited. Because it has been shown that excessive $\mathrm{NaOH}$ will lead to further degradation of organic acids [10, 23, 24].

\section{Effect of NiO Concentration on Cornstalks Conversion to Lactic Acid}

As shown in Fig. 2, With the increase of $\mathrm{NiO}$, the yield of lactic acid shows a trend of increasing at first and then decreasing too. When the concentration of $\mathrm{NiO}$ increases from 2.5 to $3.5 \mathrm{~mol} / \mathrm{L}$, the yields of lactic acid increased from $13.9 \%$ to $15.3 \%$, indicating appropriate amount of $\mathrm{NiO}$ can promote the conversion of cornstalks to lactic acid. By the XRD analysis shown by Fig. 3, it is found that only $\mathrm{NiO}$ is present in the solid sample after reaction, confirming the valence state of nickel oxide does not change before and after the reaction. In addition, there are lots of studies indicate that $\mathrm{NiO}$ can be used as catalysts for many organic transformation reactions [25-28]. Therefore, $\mathrm{NiO}$ may play an important role as catalyst in the process of this reaction. It can catalyze corn straws into lactic acid and other organic acids under hydrothermal condition.

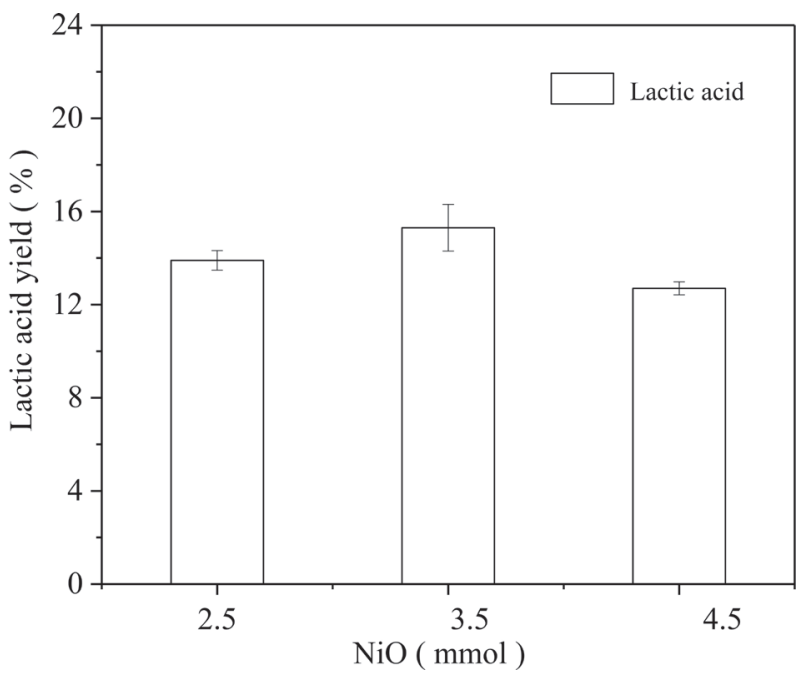

Fig. 2. Effect of $\mathrm{NiO}$ concentration on cornstalks conversion to lactic acid $\left(3 \mathrm{~h}, 230^{\circ} \mathrm{C}, 1.2 \mathrm{~g}\right.$ cornstalks, $\left.3 \mathrm{~mol} / \mathrm{L} \mathrm{NaOH}\right)$.

\section{Effect of Reaction Temperature on Cornstalks Conversion to Lactic Acid}

Fig. 4 illustrates the effect of reaction temperature on cornstalks conversion to lactic acid. With the increase of temperature, the yield of lactic acid showed a trend of gradual increase. When the reaction temperature is $180^{\circ} \mathrm{C}$, the lactic acid yield is $8.3 \%$, when the temperature is increased to $230^{\circ} \mathrm{C}$, the lactic acid yield is $15.3 \%$, which is an increase of $7.0 \%$ compared with $180^{\circ} \mathrm{C}$. When the reaction temperature was increased to $250^{\circ} \mathrm{C}$, the lactic acid yield was $16.6 \%$, which was $8.3 \%$ higher than that at $180^{\circ} \mathrm{C}$. As the temperature increases, the lactic acid yield gradually increases. The reason may be that the increase of temperature promotes the conversion of corn straw to lactic acid catalyzed by NiO. What's more, the main component of corn straws is cellulose. As the temperature increases, the solubility and

\section{$\square \mathrm{NiO}$}

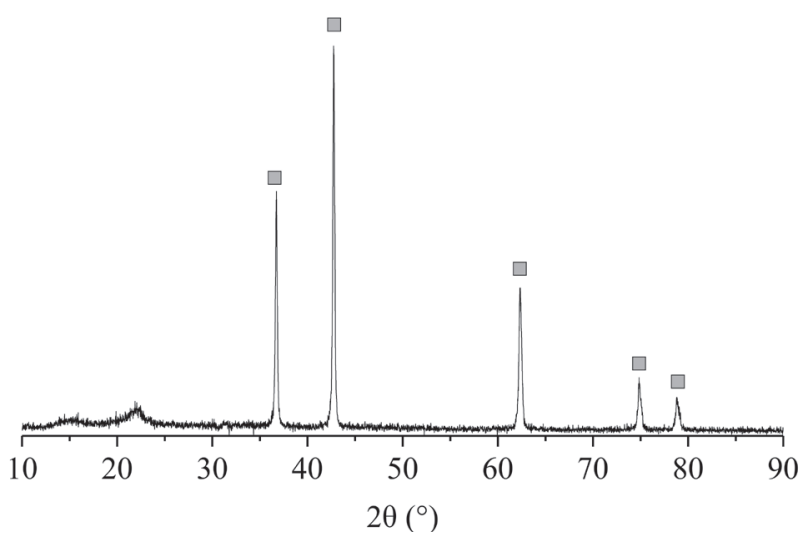

Fig. 3. XRD pattern of solid sample after the reaction of chlorella with $\mathrm{NiO}\left(3 \mathrm{~h}, 230^{\circ} \mathrm{C}, 1.2 \mathrm{~g}\right.$ cornstalks, $\left.3 \mathrm{~mol} / \mathrm{L} \mathrm{NaOH}\right)$. 


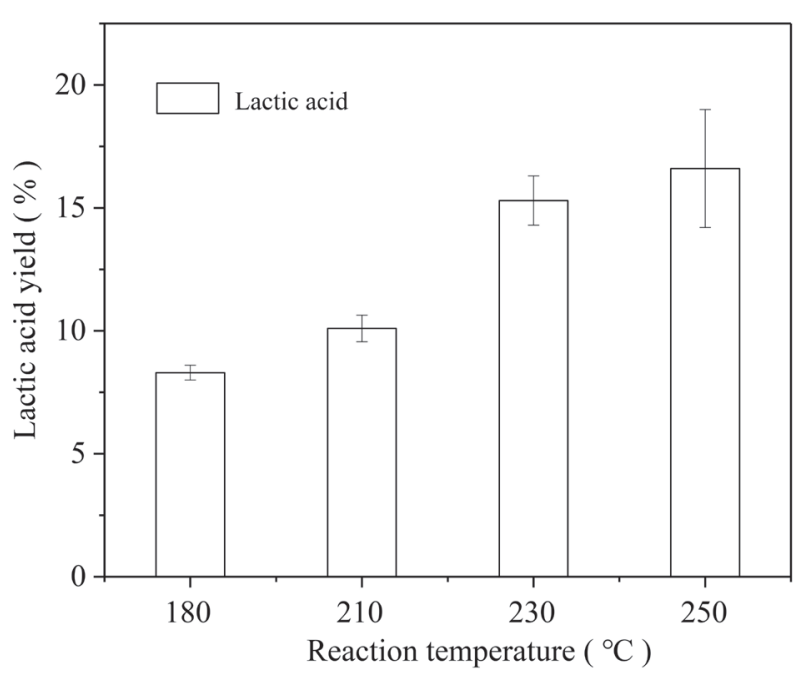

Fig. 4. Effect of reaction temperature on cornstalks conversion to lactic acid (3 h, $1.2 \mathrm{~g}$ cornstalks, $3 \mathrm{~mol} / \mathrm{L} \mathrm{NaOH}, 3.5 \mathrm{mmol} \mathrm{NiO})$.

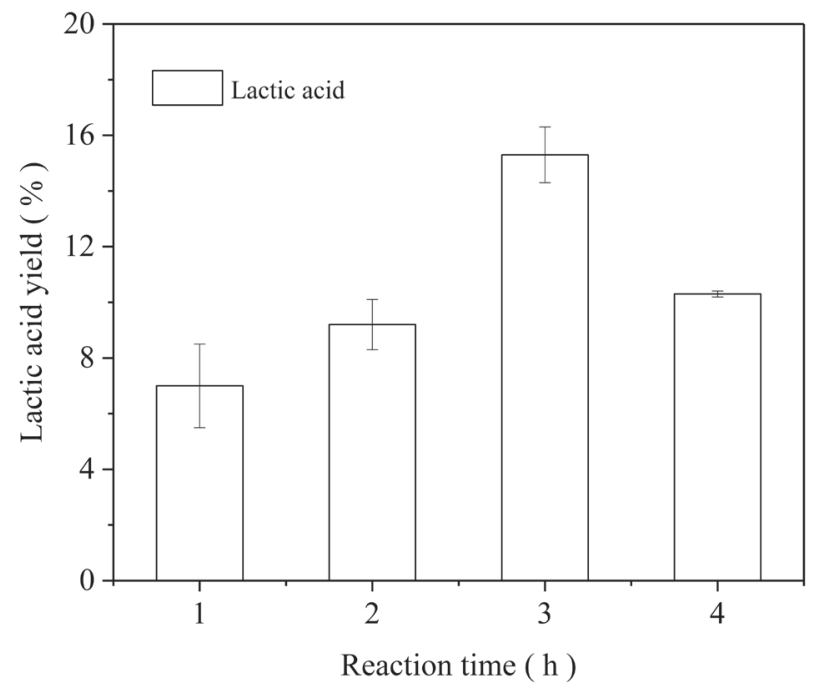

Fig. 5. Effect of reaction time on cornstalks conversion to lactic acid (1.2 g cornstalks, $3 \mathrm{~mol} / \mathrm{L} \mathrm{NaOH}, 3.5 \mathrm{mmol} \mathrm{NiO})$.

degradation of cellulose also increase [29]. It can also be seen from Fig. 4 that when the temperature increases from $230^{\circ} \mathrm{C}$ to $250^{\circ} \mathrm{C}$, the temperature increases by $20^{\circ} \mathrm{C}$, while the yield of lactic acid increases by only $1.3 \%$. Therefore, from the perspective of energy utilization, $230^{\circ} \mathrm{C}$ is the appropriate reaction temperature for the conversion of corn straw to lactic acid.

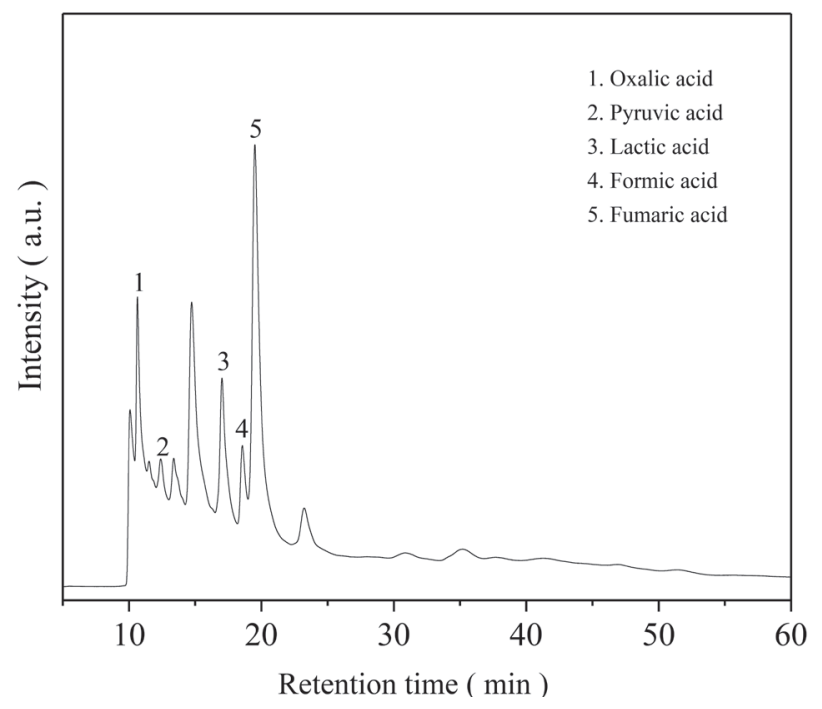

Fig. 6. HPLC chromatograms of liquid samples in the presence of $\mathrm{NiO}\left(3 \mathrm{~h}, 230^{\circ} \mathrm{C}, 1.2 \mathrm{~g}\right.$ cornstalks, $1 \mathrm{~mol} / \mathrm{L} \mathrm{NaOH}, 3.5 \mathrm{mmol}$ $\mathrm{NiO})$.

\section{Effect of Reaction time on Cornstalks Conversion to Lactic Acid}

As seen in Fig. 5, With the increase of reaction time, the yield of lactic acid in the liquid product showed a trend of increasing at first and then decreasing. When the reaction time is 1 hour, the yield of lactic acid is $7.0 \%$. When the time increase to 3 hours, the yield is increased to $15.3 \%$. The increment is $8.3 \%$. But if the time is extended to 4 hours, the yield decreased to $10.3 \%$ instead. It can be seen, with the increase of reaction time in a certain limit, the conversion of corn straws to lactic acid is promoted. But if the time is too long, the lactic acid will degrade in high temperature water [4]. When the rate of lactic acid formation is slower than the rate of degradation, the yield is decreased [30].

\section{Proposed Mechanism for the Conversion of Cornstalks to Lactic Acid with $\mathrm{NiO}$}

The main components of cornstalks are cellulose and lignin, and cellulose can be hydrolyzed into glucose monomer under the chemical action of alkali or acid. HTW has acid-base catalysis [14], so cellulose is first hydrolyzed to glucose, and then glucose can be catalyzed by $\mathrm{NiO}$ to transform into lactic acid under alkaline hydrothermal conditions (Table 2), with

Table 2. the yield of lactic acid from the conversion of glucose and o-methoxyphenol respectively.

\begin{tabular}{|c|c|c|c|}
\hline Entry & Substrate & Reaction time (h) & Lactic acid yield (\%) \\
\hline 1 & glucose & 3 & $21.4 \pm 3.6$ \\
\hline 2 & o-methoxy-phenol & 3 & $7.1 \pm 0.1$ \\
\hline
\end{tabular}

Reaction conditions: $3 \mathrm{~h}, 230^{\circ} \mathrm{C}, 10 \mathrm{ml} \mathrm{H} 2 \mathrm{O}, 3 \mathrm{~mol} / \mathrm{L} \mathrm{NaOH}, 3.5 \mathrm{mmol} \mathrm{NiO}$. glucose: $1.3 \mathrm{~g}$; o-methoxy-phenol: $0.7 \mathrm{~g}$. 


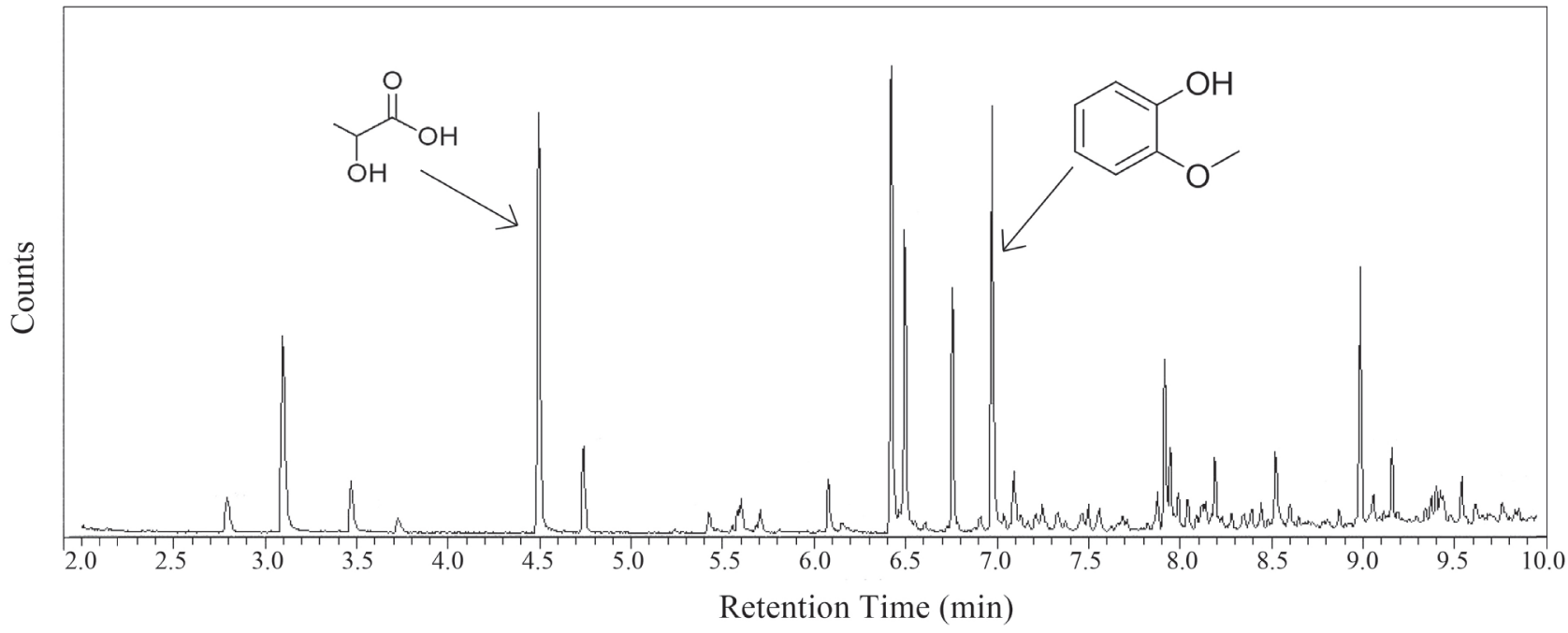

Fig. 7. GC-MS chromatograms of samples after esterfying with sulfuric acid-methanol solution $\left(3 \mathrm{~h}, 230^{\circ} \mathrm{C}, 1.2 \mathrm{~g}\right.$ cornstalks, $1 \mathrm{~mol} / \mathrm{L}$ $\mathrm{NaOH}, 3.5 \mathrm{mmol} \mathrm{NiO}$ ) The GC-MS chromatographic peaks are not calibrated and only qualitative information is given (The chemical structure and names before esterification).

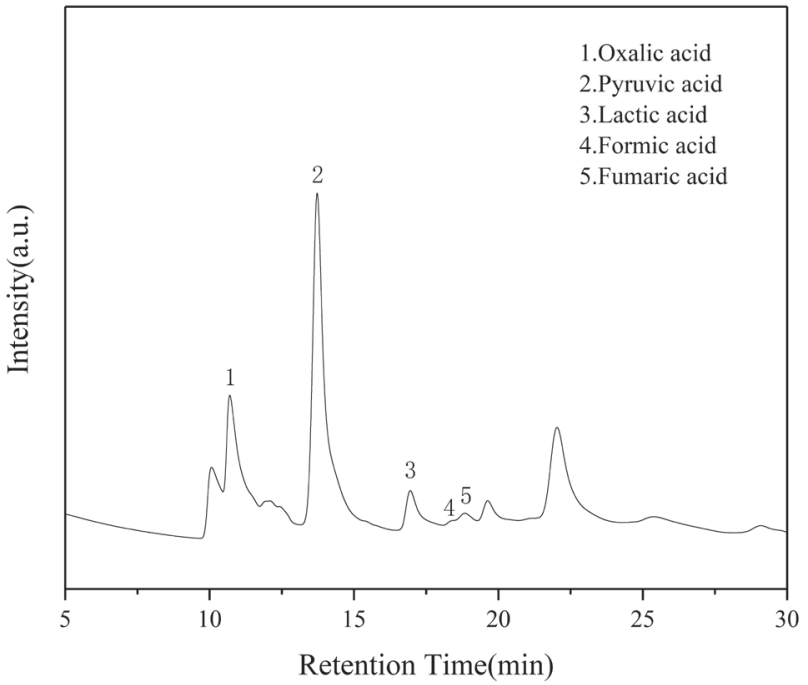

Fig. 8. HPLC analysis of liquid phase products of guaiacol oxidation catalyzed by $\mathrm{NiO}$ (guaiacol: $0.5 \mathrm{~mol} / \mathrm{L}$, NiO: $\left.3.5 \mathrm{mmol}, \mathrm{NaOH}: 1.0 \mathrm{~m}, 230^{\circ} \mathrm{C}, 3 \mathrm{~h}\right)$. a lactic acid yield of $21.4 \%$. The presence of lactic acid is detected by HPLC analysis of the liquid samples after the reaction (Fig. 6). In addition, there also are organic acids such as oxalic acid, pyruvic acid, formic acid and fumaric acid. Furthermore, lactic acid is also detected in GC-MS analysis after the liquid samples esterfying with sulfuric acid-methanol solution (Fig. 7). As can be seen from Table 2, when guaiacol is used as the reactant, lactic acid and other organic acids are also detected in the liquid products after the reaction (Fig. 8). According to the product analysis and the existing research results $[15,20,22,31-36]$, a possible reaction path for the conversion of straw to lactic acid catalyzed by nickel oxide was proposed (Fig. 9). As to cellulose, initially, it is hydrolyzed to cellobiose and then glucose under alkaline conditions. Subsequently, glucose is decomposed to threecarbon glyceraldehyde and dihydroxyacetone with $\mathrm{NiO}$, which are isomerized by the Lobryde BruynAlberda van Ekenstein (LBAE) transformation.

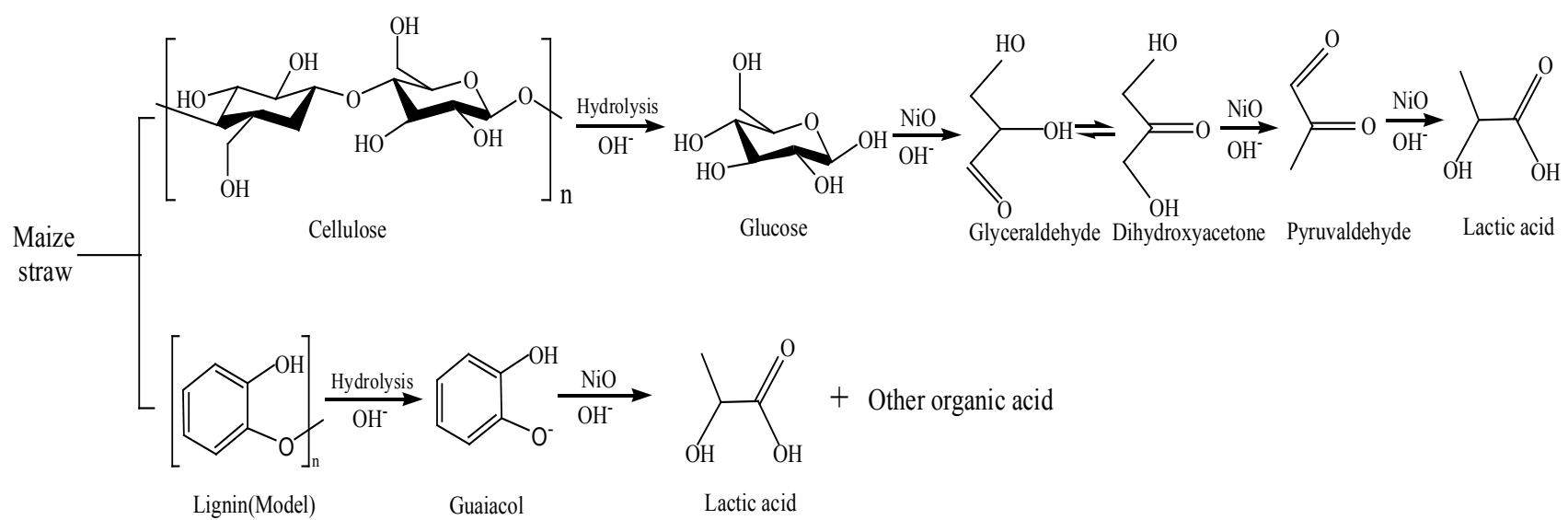

Fig. 9. Proposed Pathways of the Conversion of cornstalks into lactic acid with NiO. 
Then, the isomers lose water to form pyruvaldehyde Finally, pyruvaldehyde undergoes a benzilic acid rearrangement to form lactic acid. As to lignin, it is easily depolymerized to guaiacol monomer under alkali hydrothermal conditions, followed by degraded to lactic acid based on our previous report.

\section{Conclusions}

We have demonstrated that, in the cornstalks conversion into lactic acid with $\mathrm{NiO}$ as solid oxidant under hydrothermal condition, the conversion rate can be improved by fitting appropriate concentration of $\mathrm{NaOH}$ and $\mathrm{NiO}$, reaction temperature and time. Under the optimal conditions, the lactic acid yield can reach $15.3 \%$. Moreover, we give a proposed mechanism for the conversion of cornstalks to lactic acid with $\mathrm{NiO}$. The investigations of cornstalks conversion into lactic acid have great significance in the resource utilization of rural straw biomass waste and green production of high value-added chemical products. This method of producing lactic acid is more efficient than the traditional fermentation method, and saves more energy than using fossil energy to produce lactic acid. Therefore, it is a promising production method. At the same time, the organic acid produced can directly prepare organic snow melting agent without separation, which has higher added value and is more conducive to the application of this method in large-scale industrial production.

\section{Acknowledgments}

The authors gratefully acknowledge the financial support of the Projects of Foundation of Education Department in Anhui Province (KJ2019A0208), and the National Key R\&D Program of China (2016YFD0300205-03, 2018YFD0300905).

\section{Conflict of Interest}

The authors declare no conflict of interest.

\section{References}

1. LI H., RIISAGER A., SARAVANAMURUGAN S., PANDEY A., SANGWAN R.S., YANG S., LUQUE R. Carbon-Increasing catalytic strategies for upgrading biomass into energy-intensive fuels and chemicals. Acs Catalysis, 8 (1), 148, 2018.

2. ZHANG Z.H., YANG Q.W., CHEN H., CHEN K.Q., LU X.Y., OUYANG P.K., FU J., CHEN J.G.G. In situ hydrogenation and decarboxylation of oleic acid into heptadecane over a $\mathrm{Cu}-\mathrm{Ni}$ alloy catalyst using methanol as a hydrogen carrier. Green Chemistry, 20 (1), 197, 2018.
3. LIN W.W., CHEN H., LI J., CHEN K.Q., LU X.Y., OUYANG P.K., FU J. Enhanced stability of $\mathrm{Pt} / \mathrm{C}$ by the atomic layer deposition of porous MOx for the decarboxylation of oleic acid. Catalysis Communications, 123, 59, 2019.

4. ZHANG Z.H., CHENG H., CHEN H., LI J., CHEN K.Q., LU X.Y., OUYANG P.K., FU J. Catalytic Fast Pyrolysis of Rice Straw to Aromatics over Hierarchical HZSM-5 Treated with Different Organosilanes. Energy \& Fuels, 33 (1), 307, 2019.

5. ZHONG H., MA L., ZHU Y.Y., JIN B.B., WANG T.F., WANG Y.G., JIN F.M. Hydrothermal conversion of microalgae and its waste residue after biofuel extraction to acetic acid with $\mathrm{CuO}$ as solid oxidant. Journal of Supercritical Fluids, 157, 2020.

6. YAKOVLEV V.A., KHROMOVA S.A., SHERSTYUK O.V., DUNDICH V.O., ERMAKOV D.Y., NOVOPASHINA, V.M., LEBEDEV M.Y., BULAVCHENKO O., PARMON V.N. Development of new catalytic systems for upgraded bio-fuels production from bio-crude-oil and biodiesel. Catalysis Today, 144 (3-4), 362, 2009.

7. LI H., LIU Z., ZHANG Y., LI B., LU H., DUAN N., LIU M., ZHU Z., SI B. Conversion efficiency and oil quality of low-lipid high-protein and high-lipid low-protein microalgae via hydrothermal liquefaction. Bioresource Technology, 154, 322, 2014.

8. ZHANG Y.W., LI T.T., SHEN Y.B., WANG L., ZHANG H., QIAN H.F., QI X.G. Extrusion followed by ultrasound as a chemical-free pretreatment method to enhance enzymatic hydrolysis of rice hull for fermentable sugars production. Industrial Crops and Products, 149, 2020.

9. ZHOU X.P., WANG F., HU H.W., YANG L., GUO P.H., XIAO B. Assessment of sustainable biomass resource for energy use in China. Biomass \& Bioenergy, 35 (1), 1, 2011.

10. WANG B., SHEN X., CHEN S., BAI Y.C., YANG G., ZHU J.P., SHU J.C., XUE Z.Y. Distribution characteristics, resource utilization and popularizing demonstration of crop straw in southwest China: A comprehensive evaluation. Ecological Indicators, 93, 998, 2018.

11. ZHANG S., ZHOU S., YANG X., XI W., ZHENG K., CHU C., JU M., LIU L. Effect of operating parameters on hydrothermal liquefaction of corn straw and its life cycle assessment. Environ Sci Pollut Res Int, 27 (6), 6362, 2020.

12. ZENG X.Y., MA Y.T., MA L.R. Utilization of straw in biomass energy in China. Renewable \& Sustainable Energy Reviews, 11 (5), 976, 2007.

13. SASAKI M., ADSCHIRI T., ARAI K. Fractionation of sugarcane bagasse by hydrothermal treatment. Bioresource Technology, 86 (3), 301, 2003.

14. AKIYA N., SAVAGE P.E. Roles of water for chemical reactions in high-temperature water. Chemical Reviews, $102(8), 2725,2002$.

15. GAO X.Y., ZHONG H., YAO G.D., GUO W.M., JIN F.M. Hydrothermal conversion of glucose into organic acids with bentonite as a solid-base catalyst. Catalysis Today, 274, 49, 2016.

16. TAUBLAENDER M.J., REITER M., UNTERLASS M.M. Exerting Additive-Assisted Morphological Control during Hydrothermal Polymerization. Macromolecular Chemistry and Physics, 219 (3), 2018.

17. CHANG Y.L., SASAKI T., RIBAS-ARINO J., MACHIDA M., SHIGA M. Understanding Competition of Polyalcohol Dehydration Reactions in Hot Water. Journal of Physical Chemistry B, 123 (7), 1662, 2019. 
18. SASAKI M., KABYEMELA B., MALALUAN R., HIROSE S., ARAI K.J.J.S.F. Cellulose hydrolysis in subcritical and supercritical water, 13 (1), 261, 1998.

19. ZHANG S., JIN F., HU J., HUO Z. Improvement of lactic acid production from cellulose with the addition of $\mathrm{Zn} /$ $\mathrm{Ni} / \mathrm{C}$ under alkaline hydrothermal conditions. Bioresource Technology, 102 (2), 1998, 2011.

20. WANG F.W., WANG Y.Q., JIN F.M., YAO G.D., HUO Z.B., ZENG X., JING Z.Z. One-Pot Hydrothermal Conversion of Cellulose into Organic Acids with $\mathrm{CuO}$ as an Oxidant. Industrial \& Engineering Chemistry Research, 53 (19), 7939, 2014.

21. LI J.F., YAN R., XIAO B., LIANG D.T., LEE D.H. Preparation of nano-NiO particles and evaluation of their catalytic activity in pyrolyzing biomass components. Energy \& Fuels, 22 (1), 16, 2008.

22. YAO G.D., ZENG X., LI Q.J., WANG Y.Q., JING Z.Z., JIN F.M. Direct and Highly Efficient Reduction of $\mathrm{NiO}$ into $\mathrm{Ni}$ with Cellulose under Hydrothermal Conditions. Industrial \& Engineering Chemistry Research, 51 (23), 7853, 2012.

23. COSTINE A., LOH J.S.C., POWER G., SCHIBECI M.MCDONALD R.G. Understanding Hydrogen in Bayer Process Emissions. 1. Hydrogen Production during the Degradation of Hydroxycarboxylic Acids in Sodium Hydroxide Solutions. Industrial \& Engineering Chemistry Research, 50 (22), 12324, 2011.

24. COSTINE A., LOH J.S.C., BUSETTI F., JOLL C.A., HEITZ A. Understanding Hydrogen in Bayer Process Emissions. 3. Hydrogen Production during the Degradation of Polyols in Sodium Hydroxide Solutions. Industrial \& Engineering Chemistry Research, 52 (16), 5572, 2013.

25. WANG R., YU X.Q., BAI J.M., LI H., HUANG X.J., CHEN L.Q., YANG X.Q. Electrochemical decomposition of $\mathrm{Li}_{2} \mathrm{CO}_{3}$ in $\mathrm{NiO}-\mathrm{Li}_{2} \mathrm{CO}_{3}$ nanocomposite thin film and powder electrodes. Journal of Power Sources, 218, 113, 2012.

26. ANANIKOV V.P. Nickel: The „Spirited Horse“ of Transition Metal Catalysis. Acs Catalysis, 5 (3), 1964, 2015.

27. TAN P., SHYY W., WU M.C., HUANG Y.Y., ZHAO T.S. Carbon electrode with $\mathrm{NiO}$ and $\mathrm{RuO}_{2}$ nanoparticles improves the cycling life of non-aqueous lithium-oxygen batteries. Journal of Power Sources, 326, 303, 2016.

28. KERRU N., GUMMIDI L., MADDILA S.N., GANGU K.K., JONNALAGADDA S.B. Four-component rapid protocol with nickel oxide loaded on fluorapatite as a sustainable catalyst for the synthesis of novel imidazole analogs. Inorganic Chemistry Communications, 116, 2020.

29. ZHANG S.F., ZHANG L.L., QIAN L.W., YANG J.F., AO Z.F., LIU W.Q. Facile, Sustainable, and ChemicalAdditive-Free Synthesis of Monodisperse Carbon Spheres Assisted by External Pressure. Acs Sustainable Chemistry \& Engineering, 7 (8), 7486, 2019.

30. YAN X.Y., JIN F.M., TOHJI K., KISHITA A., ENOMOTO H. Hydrothermal Conversion of Carbohydrate Biomass to Lactic Acid. AIChE Journal, 56 (10), 2727, 2010.

31. LI Q.J., YAO G.D., ZENG X., JING Z.Z., HUO Z.B., JIN F.M. Facile and Green Production of $\mathrm{Cu}$ from $\mathrm{CuO}$ Using Cellulose under Hydrothermal Conditions. Industrial \& Engineering Chemistry Research, 51 (7), 3129, 2012.

32. MA Z., HU J.J., YAO G.D., DUO J., JIN B.B., JIN F.M. Valorization of wheat straw: Rapid reduction of $\mathrm{CuO}$ into $\mathrm{Cu}$ and production of organic acids under mild hydrothermal conditions. Process Safety and Environmental Protection, 115, 79, 2018.

33. YIN G., HUO Z., ZENG X., YAO G., JING Z, JIN F. Reduction of $\mathrm{CuO}$ into $\mathrm{Cu}$ with Guaiacol as a Model Compound of Lignin with a Homogeneous Catalyst of $\mathrm{NaOH}$. Ind. Eng. Chem. Res. 53, 7856, 2014.

34. SASAKI M., FANG Z., FUKUSHIMA Y., ADSCHIRI T., ARAI K. Dissolution and hydrolysis of cellulose in subcritical and supercritical water. Industrial \& Engineering Chemistry Research, 39 (8), 2883, 2000.

35. YIN G.D., JIN F.M., YAO G.D., JING Z.Z. Hydrothermal Conversion of Catechol into Four-Carbon Dicarboxylic Acids. Industrial \& Engineering Chemistry Research. 54 (1), 685, 2015.

36. WANG Y.Q., WANG F.W., LI C.J., JIN F.M. Kinetics and mechanism of reduction of $\mathrm{CO}_{2}$ by glycerol under alkaline hydrothermal conditions. International Journal of Hydrogen Energy. 41 (21),: 9128, 2016. 
